\title{
The Role Women in Improving Islamic Perspektif of The Current Context
}

\author{
Ana Andriani ${ }^{1}$, Wakhudin ${ }^{2}$ \\ \{ana.andriani@gmail.com ${ }^{1}$,wakhudin@ump.ac.id $\left.{ }^{2}\right\}$
}

Universitas Muhammadiyah Purwokerto

\begin{abstract}
This paper intends to interpret the role of women in the present context in the Islamic perspective. The role of women described as "pillars of the state" is a huge force to raise and educate their children, accompany their husbands on the one hand, and a woman who works in the public sector on the other. Women must raise various problems faced, both in family matters, their roles as children, mothers and wives, as well as issues related to their roles outside the public sector. All need wisdom to solve it. Modern women living today have much better freedom than the era of R.A. Kartini. In fact, due to advances in science and technology, women have a greater chance than men in competing for employment. So many jobs that were previously dominated by men can now be done by women. But all parties must also be wise in dealing with this gender issue. Because, women are faced with domestic duties, so that they do not always work in the public sphere. In the matter of polygamy, Muslim women do not need to worry because this marriage is carried out in a certain context, if all parties are fine. If you are worried that something is wrong, then Islam recommends marrying only one woman.
\end{abstract}

Key words: women, Islam, global era

\section{Introduction}

The existence of Indonesian women since entering the 21 st century has become increasingly visible, surpassing the achievements of men. This phenomenon is seen in educational institutions. Look at the achievements of women, out of the top 10 in the ranking of outstanding students in the class, 9 of them are women. Only 1 male who achieved. This is usually not the 1st, 2nd, or 3rd rank, but always above the 5th rank. The top five achievements are mostly dominated by women. This symptom is probably due to the advancement of science and technology.

Advances in information technology, in particular, "drown" boys in the fun of playing gadgets, both for playing games, chatting, social media, and the various applications provided by technology. As a consequence, the young male generation tends to ignore learning programs in schools. Meanwhile, women are more diligent in their work, including paying more attention to class and school program subjects. Every class activity is always followed carefully. Homework is done well, and the teaching and learning process in the classroom is followed proportionately.

Advances in information technology do bring new "delinquency" for students, both male and female students. The delinquency that often occurs in men is that they are deprived of their attention to play with information technology. If children use technology for productive activities, it really doesn't matter, it can even provide added value, because it can be a place to 
express creativity and innovation. But what happens in general, boys use technology for counterproductive activities, such as excessive chatting, playing games indefinitely, and accessing pornography. Uncontrolled counterproductive activity causes boys' achievement in class to stagnate in the lower ranks.

Symptoms of "delinquency" in girls are almost the same, immersed in the sophistication of science and technology. But women prefer a different segmentation, for example, they prefer Korean dramas. Liking K-Pop is actually a normal symptom, but spending the whole night watching drama fragments makes them physically tired during the day, so they are not ready to study in class. This symptom is mostly found in female students, but not as many as male students who spend their evenings "cracking" gadgets and various internet-connected devices for counterproductive activities.

As a further result, women are more likely than men to enter the world of work, especially when entering jobs that require more intellect. The intelligence that is reflected in the classroom is also reflected in the intellectuality of the test results when entering the world of work. Thus, in various recruitments for new hires, the Human Resources Department recruits more women than men if the test measures used are cognitive and soft skills. The number of new employees between men and women is no longer balanced, for example, 50\%: 50\%, but there are always more female human resources (HR) than men.

Symptoms of the increasing superiority of women are also seen in the world of work that requires masculinity. Jobs that in the past were mostly done by men were slowly being taken over by women. Workers at Filling Stations, for example, in the past were mostly men. But now they are dominated by women. In fact, many of them work night shifts. Likewise parking attendants or other manual laborers, women are increasingly filling these jobs.

When working, women also adjust more easily than men. The combination of intellectuals with their soft skills causes women to be more flexible at work and able to solve various problems better. But women workers do not have problems. The main problem for women is when they are married. Women have difficulty dividing their time between taking care of their family, both helping their husbands and taking care of their children, and working in the office. Some women have to work very hard to allocate time for family and profession, but not a few of them give up on the situation by choosing a family and neglect work in the office. In fact, many of them choose to resign from work to take care of the household and choose to live with their children.

This symptom indicates a change in gender relations between men and women, in which women increasingly dominate various aspects of life. The number of female births that is more than that of men is one of the causes, in addition to a change in work ethic between the two sexes. This phenomenon is also evidence that gender equality in Indonesia is increasingly evident, if it cannot be said that women are increasingly taking over men's opportunities.

This article at the beginning focuses more on the relationship between men and women from the perspective of feminism. Meanwhile, the next section focuses on the role of women in an Islamic perspective, especially in examining women's activities today. In the end, this paper invites all parties to find a compromise of thought between glorifying women according to the morals of the Islamic religion on the one hand, also providing opportunities for women to have careers, but still providing opportunities for men to take part in their world without having to compete with labor woman. 


\section{Literature}

Allah SWT created everything in pairs. There are day-night, morning-evening, dark-light, left-right, up-down, life-death, and also men and women. All of this is created for a harmonious relationship. Logically, if there was only one side, no other side, that would be very unlikely. As on two inseparable sides of the coin. The Quran repeatedly mentions partners in the botanical realm, it also mentions partners in a more general way, and with indefinite boundaries.

"Glory to God who has created pairs all both from what the earth has grown and from themselves and from what they do not know" (Alquran Surah Yaa Siin, 36: 36). From the very beginning, Allah created human beings so that a pair-and-partner relationship between Adam and Eve could be realized. Furthermore, the male pairs with the female, the sky pairs with the earth, the sun pairs with the moon, the day pairs with the night. Islam teaches, sin pairs with reward, heaven pairs with hell, satan pairs with angels.

With regard to the existence of women and men, a harmonious partner is ideal. They complement each other. "It is made beautiful in the human (view) of the love of what is desired: women, children, wealth of gold, silver, selected horses, livestock and fields. That is the pleasure of living in the world, and with Allah is a good place to return (heaven)" (Surah An-Nisa: 1).

\subsection{Women of Inspiration}

In human life, women are always an inspiration, the story of Jeanne d'Arc in the 15th century in France, is one of them. How she became a fire of enthusiasm for the French nation when her country was occupied by Britain. The issue of being a spreader of witchcraft, then finally being burned alive, making her a holy woman. Women cannot be separated from the society in which they live, and women are an inseparable part of an entity called family. Managing the household and partnering with the husband in the household are important roles for women in general, having an important position as intellectuals, to borrow Edward Said's thoughts in his book The Representation of Intellectuals, women as intellectuals are able to say what they think is true, whether or not they are in accordance with the thoughts of the authorities. It would be a mistake to know what to say but avoid saying it, and should never be devoted to those in power. Another unique role of women is to have the task of carrying out duties in the household and in the public sphere.

Thus it becomes clear that the position of women in the situation of living together in a country is very important. Women as the pillars of civilization have the ability to be able to reconstruct human civilization in accordance with the corridors outlined by God to them, of course by giving a touch of religious education so that their existence, potential and goodness can contribute to improvements in the formation of civilization and be able to support it when she is the first educator of mankind.

The problem today is that women face quite serious obstacles. The dual role in the public sector, which seems to be the culture of society today, has huge consequences for its continued role in the domestic sector. The existence of women outside the home often interferes with their activities in their families. In fact, the public space is wide open. Meanwhile, the reality of the community (silence majority), which is starting to be apathetic and apolitical, can be found anywhere. Emancipation that is able to bring out the extraordinary potential of women can be accepted by society without having to sacrifice the main role of women in the family. 


\subsection{Emancipation, Resistance to Polygamy}

One of the Indonesian female figures who became a source of inspiration is R.A. Kartini. She is the daughter of R.M. Adipati Ario Sosroningrat, Regent of Jepara, was born on April 21, 1879 in Mayong, Jepara Regency. Kartini is the daughter of her father's second wife. Until the age of 12, Kartini was still allowed to go to school and leave the house by her father. However, in 1892, she had to undergo seclusion, which at that time was a Javanese custom that was applied to adult women. For four years Kartini was confined in seclusion, and after being released from that confinement, she faced the obligation to marry a man she did not know. He was R. Adipati Djojo Adiningrat, the Rembang Regent who was already married. Actually, Kartini was very much against such marriage customs, but she was helpless, because "just obeying" was a value that Javanese women had to adhere to, and marrying an unknown man was a custom and a must for Javanese girls at that time.

Kartini lived in the earliest phase of Indonesian nationalism. Kartini's sense of nationality was only fought for by herself, without the support of mass organizations that did not yet exist at that time. Awareness of the fate of their nation can be listened to through resistance to polygamy, which was then entrenched among the Javanese aristocrats. In a letter to her best friend, Zeehandelaar, Kartini expressed her feelings as follows:

Once in a while I can't put love. If it's going to make love, in my opinion, there must be respect first. I have no respect for Javanese youth. How can I respect someone who is already married and who is already a father, but because he is satisfied to have married the mother of his children, bring another woman into his house, the woman whom he marries legally according to Islamic law? Who doesn't? And why not? It is not a sin, and it is not a reproach. Islamic law allows men to keep four women. Even though people say a thousand times that having four wives is not a sin according to Islamic law, I say that it is a sin. Anything that hurts others, is sin in my opinion. What is the miserable punishment that a woman must suffer, if her man returns home with another woman and that woman must be recognized as his legitimate male wife, and must be accepted as a rival? That woman can be tortured, hurt for the rest of her life to her heart's content, but if he does not want to free her again, that woman can only cry as high as the sky to ask for rights, nothing will get.

Do you understand now why I hate marriage so much? Work as low as I want to do it with a big heart and earnest, as long as I do not have to marry, and I am free. Stella, you know what a sad heart. My heart really wants to do something, but I feel really powerless to do so.

You ask whether I was originally confined in four thick walls. You think I live in an eggplant or something. No, Stella, my prison is a large house, with a large courtyard around it, but around the courtyard there are high walls. This wall is our prison. How big is our house and yard, if we always have to live there, it feels too tight. I remembered how I, because of infinite despair and sadness, then threw my body over and over again at the ever-closed door, and on that cruel stone wall. Where do I go, every time I break my way by a stone wall or a locked door.

Our whole world of bumiputera will certainly change too. The time of change is predestined by God, but what? That's the problem. We cannot speed up the time of change. Comrade, we are saying here, it would be nice if we slept first for a hundred years, and when we wake up again, then we feel we fit the situation at that time. (Excerpt from Kartini's Letter to Ms. Zeehandelaar, November 6, 1899. Quoted from R.A. Kartini, After Darkness Is Out of Light, Jakarta: Balai Pustaka, 1949, translation by Armijn Pane).

However Kartini lamented and opposed the custom, the confinement of customs and traditions in her family was stronger. She had to give up. On November 8, 1903 Kartini had to 
marry the Regent of Rembang, R. Adipati Djojo Adiningrat. On September 13, 1904, her son was born, and four days later on September 17, 1904, Kartini died.

\section{Method}

\subsection{Conflict Due to Religion}

At the time of Kartini's life, conflict over religion seemed to be prevalent in Javanese society. This condition can be seen from Kartini's outpouring in her letter to Zeehandelaar as follows:

Religion means that it will give mercy to humans, so that there will be friendship with all God's creatures. All of us brothers and sisters, not because we are the same as the father of a human birth, but we are all creatures of a Father, to Him, who reigns in the heavens. O my Lord, there are times when I wish, it would be nice if there was no religion. Because, that religion, which actually has to unite all the servants of Allah, has always been a source of strife and division, has been the cause of fights, murders which are very horrible and cruel. People who are a thousand opposites, because they have different ways of serving the One God. People who are very merciful, very sadly divorce, because different places call to God. God that too; stands the wall of a compassionate heart. Is it true that religion is a blessing for humans? I often ask myself, hesitating. Religion must keep us from sinning, but how many sins do people commit in the name of that religion? (Extract from Kartini's letter to Ms. Zeehandelaar, 6 November 1899).

\subsection{Education for Indigenous Women}

Kartini also fought for the improvement of the lives of the native people through women's education. Below are Kartini's thoughts about the importance of education for indigenous (bumiputera) women:

I have been thinking about education for a long time, especially in the last few times. I see education as a noble and sacred obligation. I see it as a crime, if I carry out the educational effort, but I don't have the full skills yet. It must be evident first, whether I am able to become an educator or not. In my opinion, education is education of mind and spirit.

It feels like an educator's obligation has not been completed if she is only educating her mind. She must also work to educate minds even though there is no law that obliges him to do so. I ask myself, can I? I still need to be educated?

With all my heart I confirm the thoughts of your husband, Madam, which is written in a circular about a teaching case for bumiputera girls: "Women are become pillars of civilization teachers!" Not because women are considered capable of that, but because I truly believe that from that woman a great effect will arise, both deteriorating and improving life. It is she who is more able to help promote human morality.

It was from women that humans first received education. It is in her day that the child learns to feel, think and speak. Increasingly, I have come to know that this initial upbringing is not insignificant for human life in the future. How could the mother of a bumiputera be able to educate her child, if they themselves are not educated?

That is why I am very excited about the noble intention of providing education and teaching for native girls. I have known for a long time, that this is what can change the lives of us sad 
native women. Teaching these girls not only to women will bring grace, but also to the entire bumiputera society (Extract from Kartini's letter to Mrs. Abendanon, January 21, 1901) translation by Armijn Pane).

Thus Kartini, with no awareness and understanding of the concept of nationalism, she cared about and had a very high sensitivity to aspects of the life of the native people that had to be improved and enhanced.

\section{Result and Discussion}

\subsection{Meaning of Gender}

The word gender means differences in roles, functions, and responsibilities between women and men which are the result of socio-cultural constructions and can change according to the times. This gender issue has an impact on status, function, role, and responsibility, to the extent that it concerns men's and women's activity spaces in society. It is as if there is discrimination against the roles of women and men, and gender injustice which affects the existence of women themselves. So women's obsession is gender equality.

Gender is often identified with sex. Gender is very different from sex. Gender is understood as a gift from God Almighty with its character. Etymologically the word "gender" comes from English which means "gender" (John M. Echols and Hassan Shadily, 1983: 265). The word "gender" can be defined as "the visible differences between men and women in terms of values and behavior" (Victoria Neufeldt (ed.), 1984: 561).

Gender can be defined terminologically as cultural expectations of men and women (Hilary M. Lips, 1993: 4). Meanwhile, according to Showalter, gender is the differentiation of men and women seen from the socio-cultural construction (Elaine Showalter (ed.), 1989: 3). Nasaruddin Umar (1999: 34) explains that gender can be used as an analytical concept that can be used to explain something. Women's Studies Encyclopedia more explicitly explains that gender is a cultural concept that is used to distinguish the roles, behaviors, mentality, and emotional characteristics of men and women that develop in society (Siti Musdah Mulia, 2004: 4).

Gender as an analysis tool is generally used by adherents of the social science school of conflict, which focuses on structural and system injustices caused by gender. The problem and need to be challenged from their analysis using gender analysis is the structure of "injustice" caused by gender roles and differences. Feminism is a word that has a meaning as a movement that starts from the assumption and awareness that women are basically oppressed and exploited, and there must be efforts to end this bad behavior towards women.

Mansour Faqih views this issue by highlighting that gender injustice is caused by four things:

1. Marginalization of women (green revolution which prioritized men over women).

2. Subordination of women by men.

3. Stereotypes (wrong views) between women and men.

4. The existence of violence in household.

There are many concerning cases related to women, apart from the four factors above, trafficking, contract marriage, are other things that deserve attention. This is due to powerlessness, low education, and weak empowerment of women's potential. Gender equality is a condition that is equal and balanced between men and women in gaining access (opportunities, opportunities) in various aspects of life. 
Feminism is an understanding and a movement that demands full equal rights between men and women. According to Fakih (1996: 78), feminism is generally a movement that originates from the assumption and awareness that women are oppressed and exploited, so there must be an effort to end oppression and exploitation.

Feminism emphasizes equal rights between women and men, both in employment, income, and equal opportunities in various ways. Like other schools of thought and movements, it is not single, but consists of various ideologies, paradigms and theories whose orientation is focused on fighting for the fate of women. So it is feminists who faithfully proclaim this gender equality.

Feminism can be categorized as an ideology, because now it is no longer a mere thought movement, but has developed into a movement that has a structural-conflict approach. In the structural-conflict approach, everything related to gender relations can be seen and placed in a contradictory and antagonistic context. The other side of feminism is the awakening of the awareness of injustice towards equal dignity and honor with men as God's creatures who are born equal.

\subsection{Women in Islamic Perspective}

Allah SWT gives intelligence to every woman. Therefore, it is to women that children are entrusted. God does not necessarily give such a big mandate, if women do not have extraordinary potential. Women should have a strong identity, so that they are able to carry out their duties properly. Mother is a nickname for women who usually have children, are already married, or are educators, also for certain age categories (for some women who feel young? There is a feeling of uncomfortable being called mother, even though they are physically adults).

For the first vocation, mother is a printer from an early generation, cannot be replaced by anyone. Even by the best and most expensive schools. So women are creatures full of potential that Allah SWT prepared to form the next generation. Being a mother today is not easy, with the times that seem endless, as well as the view of society today in seeing the mother figure, is faced with a dilemma.

"Heaven on the soles of mother's feet" becomes a series of sentences filled with the meaning that the task of women is so noble in living life on this earth, whether as children, wives, mothers, as well as in other roles. Of course this is a form of respect for women. And Islam deeply glorifies women.

Islam has a view of women by placing them so high and respect. Women also have the right to do whatever they want, as advised by the Prophet. "Give alms, O women, even from the jewelery you wear". This is proof that women still have property rights. They are free to spend their wealth as they wishes.

This statement breaks the opinion of feminists who advocate gender equality, that women are imprisoned in an Islamic perspective. In a different portion from men, women have got a noble place. So without the need to herald gender equality, women have got it. The problems faced by women today, are that women able to divide their duties, roles and responsibilities so that they can carry out their duties properly? This condition makes most women stifled if they only live at home, work as a housewife as if they are not prestigious, so on the pretext of selfactualization, economic conditions, to being bored at home, the role outside the home is taken. This is legal, if women take part in roles outside the home, as long as they remain in accordance with their nature. Interpret the sentence that Allah SWT made humans as caliphs on earth, not only men who got the task as caliphs, but all humans. Men and women without exception, through intelligence, the function of the caliph is able to carry out it. 
Concerns that women will not be anxious in carrying out their roles, women must be able to understand self-concepts. Where it comes from, what it was created for, where it will return, need to be deeply understood. Adequate education, understanding of roles, functions, status, and responsibilities as well as time management is very helpful in overcoming existing problems. So gender equality no longer needs to be voiced, because Islam has already implemented it.

\subsection{Harmonization of Women and Men}

Finding a girl who is secluded when entering adulthood today is very difficult, maybe not even there anymore. Likewise, women who are forced to marry men who do not know are getting smaller. There are still, but not many of them. Even if there is a forced marriage, it is usually the result of family problems, not because of a habit like the era of RA Kartini. If Kartini says, "After darkness, light rises", then today the Indonesian nation is in a period of bright light. Even so bright that it looks dazzled.

Yes, women now live no longer confined, but free as birds flying wherever they want. Even so free, women today are free to express their feelings without hesitation. Even when it comes to love, women express their feelings before men. In the past, women tended to be passive when it came to love. They wait for men to confess their love first. After there is confirmation from men, women then give responses commensurate with the love given by men.

In fact, in some cases, women are more aggressive in chasing the men they like. Women claim to fall in love first than men convey it. Maybe she got the love back from him, maybe she didn't. But the behavior of aggressive women is increasingly prevalent these days. Maybe they are influenced by the soap operas they often watch on television. Maybe this condition has not been encountered by women in the past, so that women generally behave passively. In the past, women who were aggressive were called rude.

Which is better, a passive woman who accepts whatever circumstances are given, or an increasingly expressive, aggressive woman who can say whatever she wants? Both are good as long as there is a sense of responsibility. A woman who is passive must accept the consequences if she gets a boyfriend from a boy she doesn't like, because she doesn't reveal who is actually the man she doesn't like. On the other hand, an aggressive woman should not be disappointed if the man who is being chased has a wife or girlfriend, so that he does not want to choose another woman. What is more precise is, to be passive to maintain politeness. Men who love women will usually chase women who are polite and careful, not women who are aggressive to him. When the situation is very important, women must also have the courage to convey their ideas, not just be silent. But even if they do talk, women don't need to talk excessively.

Apart from that, the freedom that women have, which men also have, is not used arbitrarily for counterproductive activities. Lesbian, gay, bisexual, and transgender sex can not be tolerated simply for reasons of freedom. This is because freedom means that there is a limit, there is a limit to the freedom of others. Free does not mean free to be damaged or destroyed. Meanwhile, sexual relations between lesbian, gay, bisexual, and transgender people are intrinsically damaging to humans and humanity. Having children through the relationship of a man and a woman is common, and it is only possible by having sex between a man and a woman. Beyond that it is impossible.

Although the relationship between man and woman is normal and will produce offspring, their relationship must be legal. The legal relationship between a man and a woman in Islamic perspective is marriage, which is a contract between the guardian and the groom. This ritual is a handover of responsibility from parents as guardians to the man who becomes the husband. Islamic fiqh law allows guardians (parents) to marry off their children to anyone. But in Islam, 
marriage is not just a legal issue, it also concerns ethics and morals. Although parents are free to marry their children to anyone, men who are matched must be in balance with the daughter they marry, so that it benefits them.

Islamic law also allows men to marry four women, as complained R.A. Kartini. But again, the issue of marriage is not just a legal issue, but also concerns ethics and aesthetics. The legal basis for allowing a man to marry more than one woman is the Koran Surat An-Nisaa verse (3) which means, "And if you are afraid that you will not be able to be fair to the (rights) of an orphaned woman (if you marry her), then marry a woman (other). ) that you like two, three, or four. But if you are afraid of being unfair, then (marry) just one person, or the slaves you have. This is closer to non-persecution." (Surah An-Nisaa, 3).

The above verse allows a man to marry 2,3 , or 4 women. But this verse also gives a signal about the possibility of being unfair, or at least if all parties are concerned about injustice. If both men and women are worried about injustice, the solution is to marry only one woman. At best, if there was still slavery, men could have sex with their slaves. Married with only one wife or with a slave has the opportunity for peace, without domestic fuss. That is, Islam provides an opportunity for polygamy to occur, but in certain situations, it suggests that it is enough to marry one wife or monogamy. Both polygamy and monogamy must all be adapted to the context of the husband and wife situation, not done arbitrarily.

Absolutely rejecting polygamy is not a solution to creating justice. In fact, rejecting polygamy means approving injustice. When the number of women is more than the number of men, then polygamy is a solution. With polygamy, all women get the opportunity to marry the man they love. But if polygamy is prohibited, then there will be injustice, because there are some women who are happy to get husbands, but there are others who cannot marry forever. In addition, in certain situations there are people who are so rich, but some others experience poverty. Marrying a woman to help others is part of goodness, even if you are a second, third, or fourth wife. But again, if polygamy causes no benefit, then they are advised to marry only one woman.

\section{Conclusion}

Women in their lives have dual roles, as wives and mothers. The two roles of women cannot be replaced by men. Pregnant women, giving birth, and breastfeeding then educating their children is a series of tasks that require extra attention. Such a heavy duty makes women very noble in the eyes of Islam.

The tendency for the role of women to increase in the current context makes women more able to manage their thoughts, energy, time and all their attention to remain in their nature. The role of the breadwinner, the emancipation that is touted is not wrong, because as human beings, women also have the potential that should be explored optimally so that it is useful for the benefit of society. "The best human being is the one who benefits the most for others", this can be attributed to women who have multiple roles.

The logical consequence of this dual role is that women are required to continue to learn, and work and work so that they can become the pillars of the state that can lead their children to become golden generations in the future. So the role of women in the Islamic perspective in the contemporary context does not violate their nature as real women.

Modern women from the perspective of Islam are those who have the responsibility for their choices in life. They look great by showing Islamic morals on the one hand, but they are also 
allowed to express their attitudes progressively as long as they still maintain their dignity as Muslim women. Muslim women do not have to worry about polygamy if it is necessary, be it 2,3 , or 4 women, after all, Islam also recommends that one wife is sufficient if polygamy creates a situation that causes noise and injustice.

\section{References}

[1] Al-Hadits

[2] Alquran

[3] Antonio Gramsci, Sejarah dan Budaya terjemahan dari The Prison Notebooks (Surabaya: Pustaka Promethea, 2000), hlm. 28-33.

[4] Gelap Terbitlah Terang, Jakarta: Balai Pustaka, 1949, terjemahan oleh: Armijn Pane. 